\title{
Murat Valiyev
}

(Society of Karl May School Friends, St. Petersburg, Russia)

https://orcid.org/0000-0003-2450-3414

E-mail: mvaliev@mail.ru

\section{The Stein Family - From the Legend to Reality}

\author{
Rodzina Stein - od legendy do realności
}

\begin{abstract}
The article is devoted to the family history of the Stein family. Unique genealogical information about seven generations of the family is given. According to the family legend, the Stein family moved to the Catholic Poland in the second half of the 16th century after the victory of the reformation movement in Germany. The representatives of the Stein family served to the Polish, Russian, and Austrian Crown. This paper traces the history of the Russian branch of the family, which includes officers and government officials, writers, and journalists. One of the main characters of the publication is the famous philologist and Slavist Sergey Vladimirovich Stein (1882-1955). For the first time, it was possible to precisely reconstruct the events of the last 15 years of S. V. Stein's life. The article is accompanied by a large number of illustrations, most of which are published for the first time.
\end{abstract}

Key words: genealogy, genealogical numbering system, Stein, Russia, Saint Petersburg, Derpt, Dubrovnik, Munich

\begin{tabular}{|l|l|l|l|}
\hline PUBLICATION INFO \\
\hline
\end{tabular}


Our work is devoted to the family history of the Polish immigrants, to German Stein family. The central figure of our story is the famous philologist and Slavist Sergei Stein, whose name is recorded in the chronicle of the school named by K. May, the history of which we have been working for more than ten years ${ }^{1}$.

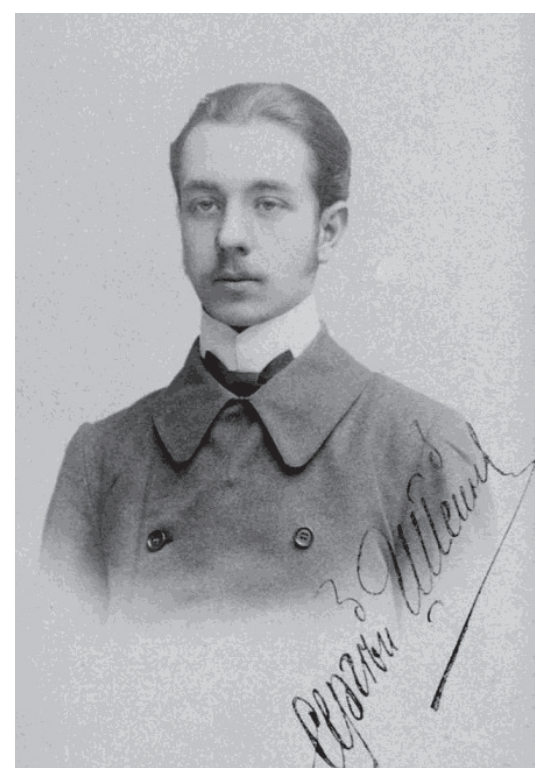

Photo 1. Sergey Vladimirovich Stein. Tsarskoye Selo, 1900².

Published for the first time.

The available publications about Sergey Stein ${ }^{3}$ are mainly devoted to his professional activities, with an emphasis on the traditionally attractive

1 Н.В. Благово, Школа на Васильевском острове, part 1, Санкт Петербург 2005; М.Т. Валиев, А.Ф. Клебанов, Прусские-русские Цейдлеры, 'История Петербурга' 2011, 3, 4; Вагнеры - от аптечной стойки до генерада флота, in: Немизы в Санкт-Петербурге. Биографический аспект, по. 9, Санкт Петербург 2015; М. Валиев, И. Аейнонен, Учитель немеиякого, 'Рыбинская среда' 2014, 5, рр. 28-31.

2 Tsentral'nyy Gosudarstvennyy Arkhiv Sankt Peterburga [hereinafter: TGASP], f. 7240 , inv. 2 , ref. no. 4025 , sheet $1 \mathrm{~b}$.

3 Б.В. Равдин, Русская филология в Тартуском университете, 'Ученые записки Тартуского университета. Труды историко-филологического факультета' 1954, рр. 162-163; Г.М. Пономарева, Воспоминания С. Штейна о поэтах-иарскоселах (И. Анненский, H.C. Гумилев, A.A. Axматова), in: Slavica Helsingiensia, vol. 11, Studia Russica Helsingiensia et Tartuensia III: Проблемы русской литературы и культуры, eds. L. Byckling, P. Pesonen, Helsinki 1992, pp. 83-92; Г. Пономарева, Т. Шор, Славист Сергей Штейн и Тартуский университет (1919-1928), in: Русские вне России: История пути, Таллин 2008, рр. 163-173; А.Б. Арсеньев, Русская әмиграция в Дубровнике. 1918-1921 г2., 'Новый журнал' 2010, 260, pp. 281-322. 
topic of the 'Silver Age' of Russia. The history of the Stein family has not been described in detail anywhere, and the available publications are full of inaccuracies and errors. However, this is partly the fault of the family members themselves, who in their biographical notes repeatedly employed wishful thinking. It is enough to mention the autobiographical notes of Vladimir Ivanovich Stein', in which it is written: 'My grandfather, Franz Ivanovich von Stein, was a Catholic and, perhaps, a Pole, although apparently he was a Polonized German, who owned land in the Volyn province. According to the stories, he or his father still held the baronial title and lived out their fortune, feuding at the sejmiks with the princes of Giedroyc ${ }^{5}$. Unfortunately, there are no family documents in the hands of the family at this time, on the basis of which it would be legally possible to say anything about the history of our family $[\ldots]^{\prime 6}$.

Based on family legends, the progenitor of the Volyn Steins was a certain Karl Philipp von Stein, who married to Henriette Caroline von Loewe had four sons, one of them, Friedrich Ludwig Stein, joined the Austrian army, and the other, Johann (Ivan) Stein joined the Russian army. In turn, Ivan Stein had three sons, Franz, Stanislav and Matvey. In the best traditions, Matvey inherited the remnants of the patrimonial lands, Franz entered the military service, and the younger Stanislav chose a spiritual path for himself, became the Catholic priest and was lately a canon in Vilna. No dates are given in the biographical notes, and no documents support this information. Over the course of archival searches, it was possible to find the service records of Franz and Matvey Stein and establish the birth years of two of Ivan Stein's three sons.

Even more fantastic is the family history described by S. V. Stein in his autobiographical book ${ }^{7}$. It should be noted that the work was written during the stay of Sergey Stein in Dubrovnik, at the time when he moved from the Orthodox to the Catholic denomination and worked closely with the higher Dominican School of Philosophy and Theology.

4 Otdel Rukopisey Instituta Russkoy Literatury [hereinafter: ORIRL], f. 541, ref. no. 1.

5 Gedroytsy - Lithuanian princely family, according to legend, leading its origin from the legendary Prince Gedrus. Separate branches of this family lived on the territory of modern Belarus, Lithuania, Russia and Ukraine.

6 'Дед мой Франц Иванович фон Штейн католик и, пожалуй, поляк, правда, повидимому, был ополяченный немец, владел землями в Волынской губ. По рассказам, он или его отец еще носили баронский титул и прожили свое состояние, враждуя на сеймиках с князьями Гедройцкими. К несчастью, в руках семьи в данное время не имеется никаких фамильных документов, на основании коих возможно было бы юридически сказать что-дибо об истории нашего рода [...]'. ORIRL, f. 541, ref. no. 1, sheet $9 \mathrm{v}$.

7 S.V. Štejn, Moj put k Bogu: Vjerske uspomene, Zagreb 1940. 
In his book, Sergey Vladimirovich claims that his ancestors from the 12th century belonged to the noble family von Stein of the Principality of Nassau, and in the second half of the 16th century the ancestor Nikolaus von Stein emigrated to the Catholic Poland, where the family lived until the end of the 18th century. At the end of the family legend, Stein talks about the marriage of his great-great-grandfather, Jan von Stein, with Princess Corsini, from the family that gave the Catholic Church of St. Andrew Corsini. The only coincidence in the presentation of the early family history in the version of S. V. Stein and V. I. Stein is a fragment about the Catholic priest Stanislav Stein, who in the version of Sergey Stein miraculously turns into Bishop ${ }^{8}$. In conclusion, Sergey Stein puts forward another doubtful hypothesis about the belonging of the Jesuit Zelensky, an associate of Hetman of Little Russia Mazepa, to their family on their mother's side? .

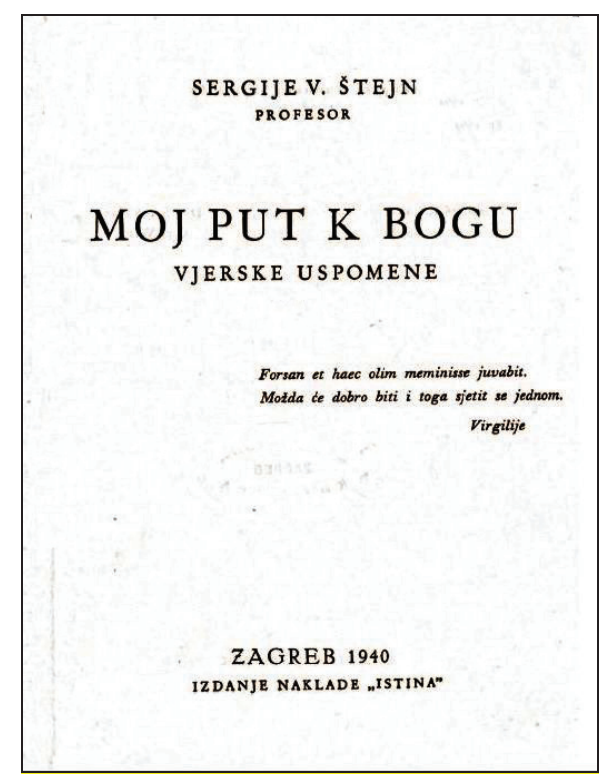

Photo 2. S.V. Štejn, Moj put k Bogu: Vjerske uspomene, Title page.

Avoiding the fascinating, hardly reliable family legends, let us turn our attention to proven and documented facts. The earliest document related to the Stein family history is the Certificate of Franz Ivanovich

\footnotetext{
8 The version is not confirmed by available sources.

9 Unlike the Jesuit ZElensky, Sergey Stein's mother's maiden name was written as ZAlenskaya.
} 
Stein ${ }^{10}$. The Certificate says that aforesaid Franz Stein, 'being from the Polish gentry of the Volyn province, joined the Polish Uhlan Regiment as a Towarzysz ${ }^{11}$ on the 1 st of July $11798^{\prime}$ was promoted to Unterofficer on the 30th of July 1799, to Sotnik on the 16th of November 1800, to Cornet on the 3rd of April, 1805 and to Poruchik on the 7th of May 1807. The combat officer took part in the campaigns and battles with Napoleon's troops in 1805 in Austria and in 1806 in Prussia. From the 8th of August 1808 to the 4th of May 1809 he was with his regiment 'in a newly acquired Finland'. On the 28th of February 1811, he was 'dismissed from the service on a personal request and assigned to the Volyn province by the Kremenets zemstvo Ispravnik, in which position he was until the 21st of April 1816'.

What conclusions can be drawn from this document? First of all, the 'Polish trace' in the history of the Stein family is confirmed. The Volyn province and Kremenets are also present in the formulary list of Matvey Ivanovich Stein ${ }^{12}$. After graduating from the Kremenets gymnasium in 1812, Matvey continued his military education in the Noble Regiment, which had been credited to his service since the 17th of February 1812.

Later on, he served in the Tobolsk and Yakut Infantry, Kamchatka Jaeger and Azov Infantry Regiments. His duty was marked by the following ranks: Praporshchik (1812), Podporuchik (1816), Poruchik (1817), Staff Captain(1820), Captain (1823), Major (1832). In 1826, he was appointed Obergevaldiger ${ }^{13}$ to the 6th Infantry Corps, the position he held until the end of 1828.

In 1813-1814, Matvey Stein took part in the foreign campaigns of the Russian troops to France and in the summer campaign of the RussianTurkish war in the European part of Turkey in 1828. During his service, he was awarded the orders of St. George, 4th class, St. Vladimir, 4th class, St. Anna, 3rd class, and the medal for the Turkish war of 1828-1829.

He finished his military service as a battalion commander of the Azov Infantry Regiment. He was dismissed for domestic reasons with the rank of Lieutenant Colonel on the 25th of January 1841. From 1843, he served as an official in the Commission for indefinite leave of natives of the Kingdom of Poland and for Invalid commands of former Polish military veterans. In the civil service, he was renamed Collegiate Assessor (1846), the last rank - Court Councillor (1848).

10 Rossiyskiy Gosudarstvennyy Istoricheskiy Arkhiv [hereinafter: RGIA], f. 1343, inv. 33, ref. no. 2704, sheet 3 .

11 'Towarzysz' was a junior cavalry officer or knight-officer in the army of the PolishLithuanian Commonwealth from the 16th century [translator's note].

12 RGIA, f. 1349, inv. 3, ref. no. 2537, sheets 5-16.

13 Gevaldiger - an officer, chief of police, with the army. 
Matvey Stein was married to a noblewoman Angelika Trofimovna Mamishcheva, and had 3 children: Pyotr, Luisa and Vladislav. Matvey himself, his wife and children kept the Roman Catholic confession.

In the case of Matvey, we can talk about a partial coincidence of realities with the family legend - Matvey Ivanovich Stein, the eldest son of Ivan Stein, is mentioned in the notes of V. I. Stein: 'Frankly speaking, the conclusion of our noble dignity from 'servitude' has always seemed unattractive to me, but the lack of family documents and the ability to enter into relations with the children of Matvey Ivanovich Stein made it impossible to collect the necessary documents for claiming the Barony ${ }^{\prime 14}$.

As follows from the Certificate of Franz Stein, the officer's combat career ended in 1809 in Finland. By this point he had married the daughter of the Mayor of Vyborg, Jacob Johann Sesemann (1762-1824) - 'baron Franz Stein, of the Polish Uhlan Regiment, married in Vyborg on the 11th of November, 1809 to Gedviga-Elizaveta Sezemann (Hedwig Elisabeth Sesemann $)^{\prime 15}$. Attention is drawn to the self-proclaimed baronial title, as we have already known at this time Franz Stein did not have title documents either only for the title or for the title of nobility. The wealthy and respectable merchant family of the Sesemanns was highly respected in the society, and the Barony was certainly important in Stein's courtship.

In this marriage, the children Anna-Alexandra ${ }^{16}$, Izydor ${ }^{17}$, Jacob-Franz and Elizaveta ${ }^{18}$ were born. Some confusion is caused by the place of birth of Franz Stein's children - according to the service record from 1811 to 1816, he served as a Kremenets zemstvo police officer in the Volyn province, and the birth of children in Vyborg can only be explained by the departure of his wife for the time of childbirth to their parents. The return of Franz Stein to Volyn, the homeland of his ancestors, can be associated with the hope of sharing the scanty inheritance and the help of his older brother. Most likely, property disputes caused discord between the relatives, and Franz decided to seek his fortune elsewhere. After requesting his resignation from the

14 'Откровенно говоря, вывод нашего дворянского достоинства из 'служилости' мне всегда казался малопривлекательным, но отсутствие фамидыных документов и возможности вступить в сношения с детьми Матвея Ивановича Штейна дишали возможности собрать необходимые документы для истребования баронского титула'. ORIRL, f. 541, ref. no. 1, sheet 5 .

15 ‘барон Франц Штейн, из польского уланского полка, женился в Выборге 11 ноября 1809 г. на Гедвиге-Елизавете Сеземан (Hedwig Elisabeth Sesemann)’, http:// dokumente.ios-regensburg.de/amburger/index.php?id=45691\& mode=1 [accessed on: 2 VIII 2016].

16 Ibidem.

17 RGIA, f. 1343, inv. 33, ref. no. 2704, sheet 61v.

18 It is mentioned in the notes of V.I. Stein. ORIRL, f. 541, ref. no. 1, sheet 10. 
post of Ispravnik, Franz moved to the Saratov province, where on the 20th of December 1817, he was appointed an official of various assignments in the Saratov State Chamber. On the 20th of December 1820 'for the riots and abuses found on the drinking part, which consisted in the sale of wine of insufficient strength with deceptions, he was excommunicated and put on trial by the Saratov Chamber of the Criminal Court, according to which a fine of 200 rubles was imposed for weak supervision of the post ${ }^{\prime 19}$.

The damaged reputation did not allow Franz Stein to continue his career as a civil servant, and in the early 1820s he entered the service of Count Dmitry Nikolaevich Sheremetev ${ }^{20}$ as a manager of the estates in the Yaroslavl province. The death of Franz's first wife, Hedwig-Elisabeth, dates from this period. The children from Franz Stein's first marriage were brought up by their grandparents. From the absence of references in the family chronicle of Anna Alexandra and Jacob-Franz, it can be assumed that only Izydor and Elizaveta lived to adulthood. Franz Stein remained a widower for a short time and soon ${ }^{21}$ tied his life with the beautiful (according to the memoir of their grandson) daughter of the retired Captain Vasily and Olga Ivanovna Logvinov, Varvara Vasilyevna. The Logvinov family was assigned to the Yaroslavl province ${ }^{22}$ and belonged to the well-born but not rich nobility. According to the great-grandson of Franz, Sergey Stein ${ }^{23}$, the bride stipulated the transition of the groom to Orthodoxy as an indispensable condition of marriage. From that moment on, all the Steins on the line of Franz Ivanovich belonged to the Orthodox faith.

The children, Alexander, Ivan, Arkady, Nikolay, Mikhailo and Maria, were born in the marriage of Franz with Varvara Vasilyevna.

Franz Stein's three sons, Izydor, Ivan, and Mikhail, chose the military service. We were able to gather quite complete information about them. The grandfather of the main character of our story, Ivan Franzevich Stein, was born on the 6th of January 1825 in the town of Balandinsk of the Atkarsky uyezd of the Penza province. At the baptism in the Church of the Nativity of Christ in the mentioned town ${ }^{24}$, the godparents were

19 ‘за найденные по питейной части беспорядки и здоупотребления, которые заключадись в продаже негарного вина с обмерами, отлучен и предан суду Саратовской палаты уголовного суда, по решению которого за слабый надзор по должности был наложен штраф 200 рублей'. RGIA, f. 1343, inv. 33, ref. no. 2704, sheet 2.

${ }^{20}$ Sheremetev Dmitri Nikolaevich (3.02.1803 - 12.09.1871) - Chamberlain and Hofmeister, known for his charity work. In 1820, he was a Chamber page, and in 1823, Cornet in the Cavalry Guard Regiment.

21 No later than 1823, since in 1823 their first child Alexander was born.

22 RGIA, f. 1343, inv. 24, ref. no. 2637.

${ }^{23}$ S.V. Štejn, op. cit., p. 43.

${ }^{24}$ RGIA, f. 1343, inv. 33, ref. no. 2704, sheet 23v. 
Poruchik of the Horse Artillery company, Konstantin Ivanovich Ososkov, and Ivan's grandmother, Captain's wife, Olga Ivanovna Logvinova. He was brought up in his parents' house, in 1842 he passed the tests in the Artillery Committee and joined the service as Feurwerker of the 4th class. Further service was marked by the following promotions ${ }^{25}$ : Junker (1842), examination for the rank of an officer in the field artillery (1844), Praporshchik according to the exam (1845), Podporuchik (1849), Poruchik (1851), Staff-captain (1855), Captain (1859), Lieutenant Colonel (1864), Colonel (1867). In 1849, as part of the 8th Artillery Brigade, he participated in the suppression of the Hungarian uprising, and was awarded the medal for the pacification of Hungary and Transylvania in 1849. For distinction in the battle of Debrecen, he was awarded the order of St. Annas of the 4th degree with the inscription 'For bravery'.

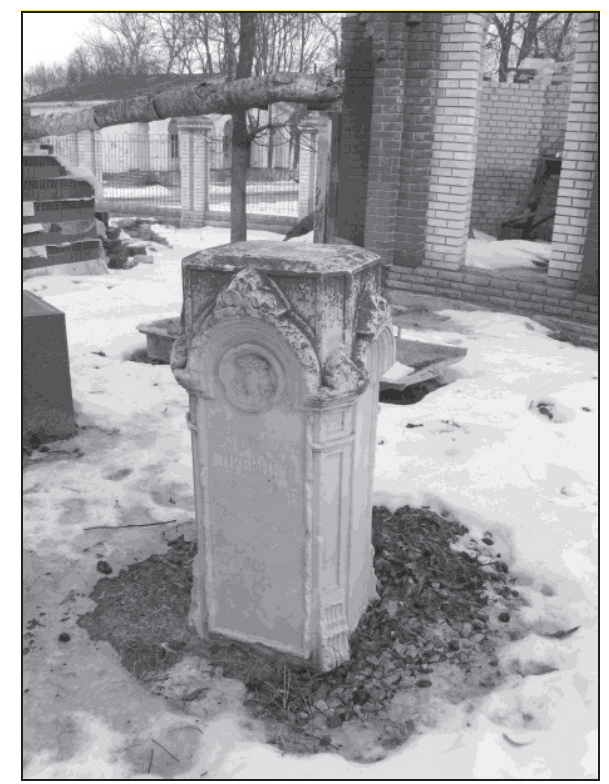

Photo 3. Tombstone from the grave of Ivan Franzevich Stein. Shostka, Ukraine, $2017^{26}$.

After the completion of the Hungarian campaign on the 25th of December 1850, he was transferred to the Shostka capsule factory, in 1858, he was assigned to the Shostka gunpowder factory and finished his

25 Rossiyskiy Gosudarstvennyy Voyenno-Istoricheskiy Arkhiv [hereinafter: RGVIA], f. 400 , inv. 12 , ref. no. 2121, sheets 59-68.

${ }_{26}$ The photo is sent by local historian Vyacheslav Dmitrievich Kirievsky (Shostka, Sumy region, Ukraine). 
career in 1871 with the rank of Colonel as the head of the Shostka capsule factory. During his service, he was awarded the order of Saint Vladimir of the 4th degree, Saint Stanislaus of the 3rd and the 2nd degrees with the Imperial crown, Saint Anna of the 2nd and 4th degrees with the inscription 'For bravery'.

On the 12th of October 1871, he 'went to work at the nearby Mikhailovsk gunpowder factory ${ }^{27}$, was thrown out of the carriage by mad horses near the factory guardhouse. He was recovered unconcious and covered with blood, and without regaining consciousness, died the next day'28.

Colonel Stein's widow, Natalia Ivanovna Stein (née Mileyko) was left with three sons - Vladimir, Eugeny and Georgy. At the time of the tragedy the eldest son, Vladimir, was studying at the Saint Petersburg Imperial University of St. Vladimir, the youngest son, Georgy, was only 11 months old. The widow survived her husband by only four years - the couple's graves were not preserved, but the tombstones were moved to the fence of the Vladimir Church in Shostka (photo 3). The age difference between the eldest and youngest son of Ivan and Natalia Stein was 17 years. In the year of Natalia Stein's death, her son Georgy was five years old. According to Sergey Stein ${ }^{29}$, Georgy was raised by his older brother Vladimir.

Ivan Stein's older brother, Izydor-Vincentius, later known as Major General Izydor Frantsevich Stein, was born on the 4th of April 1816 in Vyborg (Metrical certificate was given and signed by a military chaplain of the Lithuanian Uhlan Division ${ }^{30}$ ), was educated at the Yaroslavl Demidov Lyceum and 'spent one year in the Junior officer class of the Artillery School' (1839) $)^{31}$.

He joined the service as Unter-officer in the Grenadier Regiment of His Majesty King Frederick William IV of Prussia (1838). He began his service in the artillery in 1840 in the 17th Artillery Brigade, the last position - Adjutant to the Commander of the 1st Artillery Division. On the 30th of April 1847, he was transferred to the Shostka capsule factory. He served as Adjutant of the Inspector of gunpowder factories (1849), fulfilled the duty of the Chef of the Office of the Inspector of gunpowder factories (1851). Promoted to the rank

27 The head of the Mikhailovsk gunpowder factory was at that moment his stepbrother, Izydor Stein.

28 'отправился по службе на соседний Михайловский пороховой завод, был выброшен взбесившимися лошадьми из экипажа возде заводской гауптвахты. Поднят без чувств и в крови и, не приходя в сознание, умер на другой день'. RGVIA, f. 400 , inv. 12 , ref. no. 2121 , sheets 59-68.

29 S.V. Štejn, op. cit., p. 45.

30 RGIA, f. 1343, inv. 33, ref. no. 2704, sheets 60-61v.

31 'пробыл один год в младшем офицерском классе Артиллерийского учидища'. RGVIA, f. 409, inv. 2, ref. no. 40449, sheets 88-94. 
of Praporshchik (1839), Podporuchik (1843), Poruchik (1845), Staff-captain on the 6th of December 1849. For distinguished service he was appointed Captain on the 19th of April 1851, Lieutenant Colonel on the 17th of April 1855, Colonel (1860). In 1862, he was appointed the head of the Shostka capsule factory (we should recall that his younger brother Ivan Stein also served at this factory in 1858). In 1868, he was promoted to Major General.

In 1871, Izydor Stein handed over the post of the head of the Shostka capsule factory to his brother Ivan Stein and continued his service as commander of the Shostka Mikhailovsk powder factory, he held the position until 1880.

During his service, he was awarded the order of Saint Vladimir of the 4th degree, Saint Stanislaus of the 3rd and 2nd degrees with the Imperial crown, Saint Anna of the 2nd and 4th degrees with the inscription 'For bravery'.

After retiring from the service in 1880, with the award of the rank of Lieutenant General, he lived in Vyshny Volochok, Novgorod province, where he owned five houses ${ }^{32}$. Izydor Stein was first married to Tatiana Mikhailovna (maiden name unknown), his second marriage was to the widow of a silver manufacturer Maria Feodorovna Petz (née Bruns). In his first marriage, he had a daughter, Anna ${ }^{33}$, who married Professor of the Imperial Kazan University V. V. Zalensky ${ }^{34}$.

The Lieutenant General died in 1893 at the age of 77. In his spiritual will, he devised movable and immovable property to his wife, daughter, and nephew, Yevgeny Ivanovich Stein ${ }^{35}$.

Mikhail, the youngest of Franz Stein's sons, as well as his older brother Ivan, began his service as Feuerwerker of the 4th class in 1852. In 1854, he was promoted to Praporshchik, in 1855 - to Podporuchik, in 1857 - to Poruchik, and on the 16th of September, 1863, he was 'dismissed for the illness awarded the rank of Staff-captain ${ }^{\prime 36}$. After retirement, from 1864 to 1868 he was Assessor for the nobility in the Saratov Prikaz of common charity. In 1883, he was appointed a member of the Council and Manager of the economic part of the Saratov Mariinsky Institute ${ }^{37}$. He was awarded the order of Saint Anna of the 3rd degree, Saint Stanislaus of the 3rd, as well as the 2 nd degree.

32 RGIA, f. 613, inv. 1, ref. no. 104, sheets 70-73.

33 RGIA, f. 1343, inv. 22, ref. no. 721, sheet 1.

34 RGIA, f. 733, inv. 150, ref. no. 1151; inv. 147, ref. no. 98.

35 RGIA, f. 613, inv. 1, ref. no. 104, sheets 70-73.

36 'уволен за болезнью с награждением чином штабс-капитана'. RGIA, f. 1349, inv.

3, ref. no. 2537 , sheets $16 \mathrm{v}-17$.

37 Ibidem. 
He died no earlier than 1892, by which time he was a widow and had one daughter, Lyudmila, from his only marriage.

The eldest son from the second marriage of Franz Stein, Alexander Frantsevich Stein was born on the 16th of October, 1823 and after graduating from the Saratov gymnasium in 1841, he entered the School of Civil Engineers, which was renamed the Construction school in $1842^{38}$. However, the capital's climate proved harmful for the young man and on the 5 th of October 1846, he died of tuberculosis ${ }^{39}$.

We do not know anything about the other children of Franz Stein except their birth dates. Currently, a targeted search for descendants is underway.

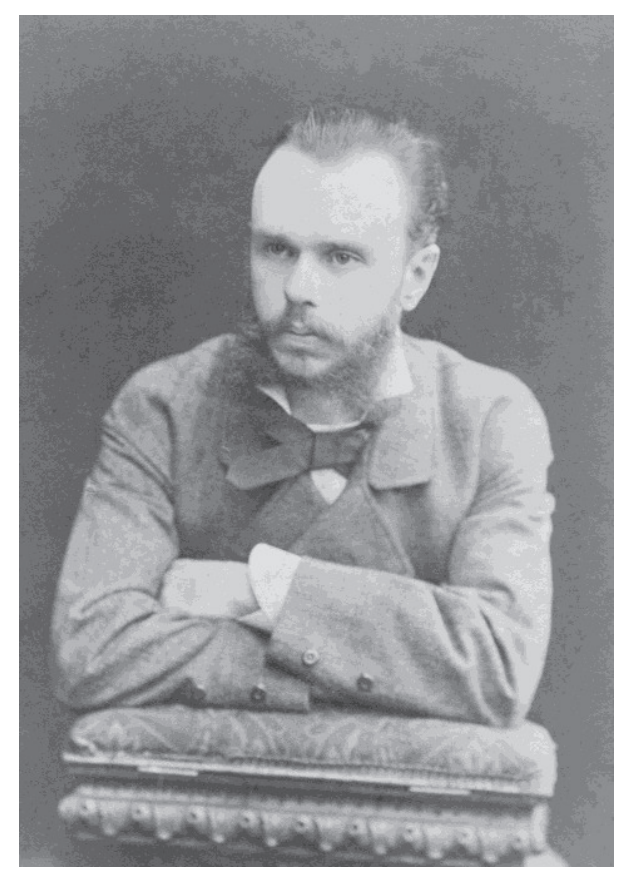

Photo 4. Vladimir Ivanovich Stein ${ }^{40}$. Published for the first time.

In the next generation of the Steins, we are interested in the repeatedly mentioned Vladimir Ivanovich Stein - the eldest son of the tragically

38 Tsentral'nyy Gosudarstvennyy Istoricheskiy Arkhiv Sankt Peterburga [hereinafter: TGIASP], f. 530, inv. 1, ref. no. 112, sheet 12.

39 Ibidem, sheet 15.

40 The photo was given by Anna Gennadievna Lazareva-Irvin, great-granddaughter of Natalia Vladimirovna Hmara-Borshchevskaya (nee von Stein) - next: 'from the archive of A.G. Lazareva-Irvin'. 
deceased Colonel Ivan Stein, the father of Sergey Stein, the author of the biographical notes and the first representative of the studied Stein family who settled in St. Petersburg.

In 1871, Vladimir Stein entered the Imperial University of St. Petersburg of Saint Vladimir ${ }^{41}$, completed higher education with the degree of Candidate of State Sciences at the Imperial Kazan University in $1876^{42}$. Soon after graduation, he was appointed an official of special assignments of the Main Field Army Treasury. As a cashier of the Field Army Treasury of the 11th Army Corps, he took part in the Russian-Turkish war of 18761878 and was awarded the medal in memory of the war between Russia and Turkey on the Saint Andrew's and Saint George's ribbon.

On the 5th of October 1878, he was dismissed from the service in the Field Army Treasury and appointed assistant clerk in the State Bank (1879). In 1880, he was assigned to the Department of Customs Duties, in which he served until the 1st of August 1894. On the 13th of July 1890, he was appointed part-time senior clerk at the Academy of Sciences. In 1896 he was appointed junior censor of the Central Committee of Foreign Censorship, while retaining his position at the Academy.

He combined public service with active literary and scientific activity - he was an actual member of the Psychological Society at Moscow University, published in the 'Труды Высочайше утвержденной Комиссии по пересмотру податей и сборов'; 'Труды Московского психологического общества'; 'Вопросы философии и психодогии'; 'Русская Старина'; 'Энциклопедический словарь Брокгауза и Ефрона'. He was the first in Russia to write biographies of Arthur Schopenhauer and G. Leopardi ${ }^{43}$. At the end of his life, he started writing the family history, as already mentioned, but unfortunately, he could not or did not have time to complete the work $^{44}$.

Vladimir Stein was married to the daughter of Major General, Elena Vladimirovna Zalenskaya ${ }^{45}$. We should remind that Vladimir's cousin,

41 RGVIA, f. 400, inv. 12, ref. no. 2121.

42 TGASP, f. 7240, inv. 2, ref. no. 4025, sheets 12-19; RGIA, f. 779, inv. 2, ref. no. 431, sheet $1 \mathrm{v}$.

43 В.И. Штейн, Гр. Дж. Аеопарди (1798-1837) и его пессимизм, Москва 1891; idem, Артур Шопенгауәр как человек и мыслитель (1788-1860): Опыт биографии, vol. 1, Санкт Петербург 1887; idem, Граф Джиакомо Иеопарди (1798-1837) и его теория infelicita, Санкт Петербург 1891.

${ }_{44}$ В.И. Штейн, Гр. Дж. Аеопарди (1798-1837) и его пессимизм, Москва 1891; idem, Артур Шопенгауәр как человек и мыслитель (1788-1860): Опыт биографии, vol. 1, Санкт Петербург 1887; idem, Граф Джиакомо Леопарди (1798-1837) и его теория infelicita, Санкт Петербург 1891.

${ }^{45}$ ORIRL, f. 541, ref. no. 1, sheets 1-13. 
Anna Isidorovna Stein, was married to Elena Vladimirovna's own brother, Professor Vladimir Vladimirovich Zalensky ${ }^{46}$. In the marriage of Vladimir and Elena Stein, the following children were born: Sergey, Natalia and the twins Sofia and Elena ${ }^{47}$.

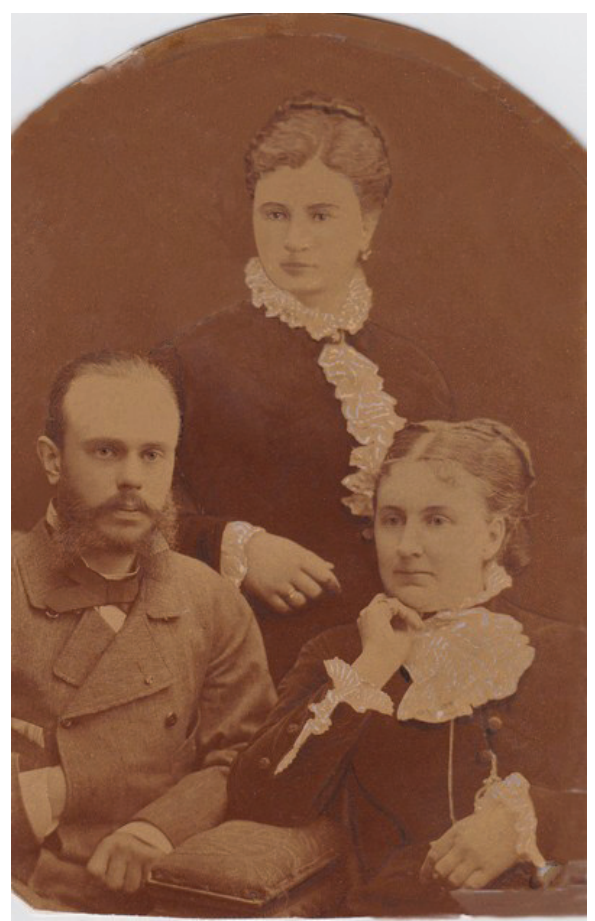

Photo 5. Vladimir Ivanovich Stein with the wife Elena Vladimirovna Zalenskaya (standing) and cousin, Anna Isidorovna Stein (?). Published for the first time ${ }^{48}$.

Many sources indicate that Vladimir Stein died in 1900, which is not true. Vladimir's last two formulary lists are dated at $1907^{49}$. One of these

46 TGASP, f. 7240, inv. 2, ref. no. 4025, sheets 12-19; [В.И. Саитов] Великий князь Николай Михайлович, Петербургский некрополь, vol. 2, Санкт Петербург 1912, p. 585; RGIA, f. 776, inv. 21, part 1, ref. no. 53, sheets 64-74.

47 Vladimir Vladimirovich Zalensky (1847-1918) - was one of the most famous Russian zoologists and embryologists. He graduated from the course of natural sciences of the Imperial Kharkov University. He was Professor at Kazan, then Novorossiysk University; from 1897 - an ordinary academician of the Imperial Academy of Sciences; until 1906 - Director of the Zoological Museum. RGIA, f. 733, inv. 147, ref. no. 98; Detailed autobiography - В.В. Заленский, [Автобиография], in: Материаль для биографического словаря действительных членов илп. Академии наук, Петроград 1915, vol. 3, part 1, pp. 298-303.

48 Photo from the archive of A.G. Lazareva-Irvin.

49 RGIA, f. 776, inv. 21, part 1, ref. no. 53, sheets $64-74$; f. 779, inv. 2, ref. no. 431. 
documents records the exact date of the death of Vladimir's wife, Elena Vladimirovna Stein - the 16th of May $1907^{50}$, which is confirmed by the data of the St. Petersburg Necropolis ${ }^{51}$. Moreover, in the case of Vladimir's daughter Sofia, dated at 1910, it is stated that 'she does not live together with her father with his consent, which is expressed in the correct monthly delivery of her means of living and education' ${ }^{52}$. Thus, we can confidently speak of the death of Vladimir Stein no earlier than 1910.

The last years of Vladimir Stein's life were far from cloudless. Almost half of his case in the funds of the Central Committee of Foreign Censorship $^{53}$ consists of Executive lists for debt collection - from quite harmless 55 rubles 'in favour of the widow of the Collegiate Councillor Maria Mikhailovna Romanova' ${ }^{54}$ to the terrifying amount of 49,850 rubles in favour of his brother Eugeny.

Sick, lonely, and entangled in debts, the father of the family was forced to retire on the 28th of April 1907 with the rank of Active State Councillor. During his service, he was awarded the orders of Saint Vladimir of the 4th degree, Saint Anna of the 2nd and 3rd degree, Saint Stanislaus of the 2nd and 3rd degree with swords and the Romanian cross for crossing the Danube.

\section{GENEALOGICAL NUMBERING SYSTEM OF THE STEINS AND THEIR DESCENDANTS}

The 1st generation

1. Ivan Stein (?, Volyn - ?).

The 2nd generation

1.1. Frants Ivanovich Stein (1780 - ?). The 1st wife: (11.11.1809, Vyborg) Gedviga-Elizaveta Sesemann ${ }^{55}$ (6.6.1788, Narva St.-Petersburg prov. - till 1823). The 2nd wife: Varvara Vasilyevna Logvinova (?-?), noblewoman.

1.2. Stanislav Ivanovich Stein (?-?).

1.3. Matvey Ivanovich Stein (1792 - ?). Wife: Angelika Trofimovna (?-?), noblewoman.

50 RGIA, f. 776, inv. 21, part 1, ref. no. 53, sheet 77.

51 [В.И. Саитов] Великий князь Николай Михайлович, op. cit., p. 585.

52 'с отцом вместе не живет с его согласия, выражающегося в исправном ежемесячном доставлении ей средств к жизни и получении образования'. TGIASP, f. 19, inv. 101, ref. no. 63, sheet 3.

53 RGIA, f. 779, inv. 2, ref. no. 431.

54 'в пользу вдовы коллежского советника Марии Михайловны Романовой'.

55 Other spelling of the last name - Sezemann. 
The 3rd generation

1.1.1. Anna Alexandra Frantsevna Stein (14.2.1811, Vyborg, Grand Duchy of Finland - ?), from the father's first marriage.

1.1.2. Isidor-Vincentius / Isidor Frantsevich Stein (4.4.1816 Vyborg, Grand Duchy of Finland-1893), from the father's first marriage. Lieutenant General. The 1st wife: Tatyana Mikhailovna. The 2nd wife: Maria Feodorovna Petz (née Bruns).

1.1.3. Yakov-Frantz Frantsevich Stein (23.7.1817 - ?), from the father's first marriage.

1.1.4. Elizaveta Frantsevna Stein (?-?), from the father's first marriage.

1.1.5. Alexander Frantsevich Stein (16.10.1823, Saratov prov. Atkarsky uy. - ?), from the father's second marriage.

1.1.6. Ivan Frantsevich Stein (6.1.1825, Saratov prov. Atkarsky uy. 14.10.1871, Shostka, Glukhovsky uy. Chernigov prov.), from the father's second marriage. Colonel. Wife: Natalia Ivanovna Mileyko (20.10.1832 18.5.1875, Shostka, Glukhovsky uy. Chernigov prov.)

1.1.7. Maria Frantsevna Stein $(1826$ - ?), from the father's second marriage.

1.1.8. Arkady Frantsevich Stein (16.9.1829, Saratov prov. Atkarsky uy. - ?), from the father's second marriage.

1.1.9. Nikolai Frantsevich Stein (16.12.1830, Saratov prov. Atkarsky uy. - ?), from the father's second marriage.

1.1.10. Mikhail Frantsevich Stein (28.1.1832 - ?), from the father's second marriage. Staff-captain.

1.3.1. Luisa Matveevna Stein (26.10.1827 - ?).

1.3.2. Pyotr Matveevich Stein (29.4.1831 - ?).

1.3.3. Vladislav Matveevich Stein (28.6.1844 - ?).

The 4th generation

1.1.2.1. Anna Isidorovna Stein, married name Zalenskaya (?-?), from the father's first marriage. Husband: Vladimir Vladimirovich Zalensky (07.02.1847, Shakhvorostovka Mirgorod uy. Poltava province. -08.10.1918, Sevastopol). Professor of Zoology at the Imperial Kazan and Novorossiysk Universities. Zoologist-embryologist.

1.1.6.1. Vladimir Ivanovich Stein (4.3.1853 - after 1910). Wife: Elena Vladimirovna Zalenskaya (22.2.1853 - 16.5.1907).

1.1.6.2. Eugeny Ivanovich Stein (26.2.1865 - ?).

1.1.6.3. Georgy Ivanovich Stein (13.11.1870 - ?).

1.1.10.1. Lyudmila Mikhailovna Stein (20.8.1870 - ?). 
The 5th generation

1.1.2.1.1. Alexandra Vladimirovna Zalenskaya (28.2.1870 - ?).

1.1.6.1.1. Sergey Vladimirovich Stein (3.5.1882, Pavlovsk, Tsarskoye Selo uyezd, St. Petersburg province - 8.9.1955, Munich). Writer, historian, journalist. 1st wife: (1904) Inna Andreyevna Gorenko (5.12.1884, Geneva - 15.6.1906, Lipitsy, Tsarskoye Selo uyezd, St. Petersburg province). 2nd wife: (1908; divorce before 1919) Ekaterina Vladimirovna Kolesova. 3rd wife: (1919) Margaret R. Frentz (2.3.1889 - ?).

1.1.6.1.2. Natalia Vladimirovna Stein (23.10.1885, Saint Petersburg - 4.1.1976, Moscow, buried at the Khovansky cemetery in Moscow). 1st husband (1905; divorce 1915): Valentin Innokentyevich Annensky (19.6.1880, Slivitskoe village, Belsky uyezd, Smolensk province - 1936, buried at the Kazan cemetery in the city of Pushkin, Leningrad region). 2nd husband: Valentin Platonovich Hmara-Borshchevsky (28.4.1895, Golovenki village, Belsky uyezd, Smolensk province - 21.5.1944, buried near Kazan, in the village of Naberezhnye Morkvashy Verkhneuslonsky district of Tatarstan).

1.1.6.1.3. Sofia Vladimirovna Stein (19.9.1888 - ?).

1.1.6.1.4. Elena Vladimirovna Stein (19.9.1888 - ?).

The 6th generation

1.1.6.1.1.1. Lyudmila Sergeevna Stein (?-?), from her father's second marriage.

1.1.6.1.2.1. Natalia Valentinovna Hmara-Borshchevskaya, married name Tombaeva (18.2.1916, Saint Petersburg - 14.6.1998, Moscow, buried at the Khovansky cemetery in Moscow) from her mother's second marriage. Husband: Nikolay Ivanovich Tombaev (9.5.1909, Illyria village, Luhansk region, Ukraine - 4.12.1999, Moscow, buried at Khovansky cemetery in Moscow), the son of an Orthodox priest who was repressed in 1937.

1.1.6.1.2.2. Innokenty Valentinovich Hmara-Borshchevsky (20.8.1917, Kamenets village, Smolensk province - 8.5.1945, Lodz, buried in the military cemetery in Zgierz, Lodz voiv., Poland), from his mother's second marriage. 1st wife: Tatyana Mashchenko. 2nd wife (1937-1945): Anna Nikolaevna Naumova (1917-1985, buried in Moscow).

The 7th generation

1.1.6.1.2.1.1. Olga Innokentievna Hmara-Borshchevskaya, married name Zavgorodnaya (b. 1938, Kharkov) from her father's first marriage. Husband: Gavriil Zavgorodny (b. 1936).

1.1.6.1.2.1.2. Valentin Innokentievich Hmara-Borshchevsky (b. 1942, Moscow) from his father's second marriage. 
1.1.6.1.2.2.1. Valentina Nikolaevna Tombaeva, married name Mamicheva (b. 14.7.1940, Moscow). Husband: Gennady Georgievich Mamichev (b. 4.6.1938, Moscow).

The main character of our essay, Sergey Vladimirovich Stein, was born on the 3rd of May 1882 in Pavlovsk near St. Petersburg and was baptized on the 26th of June 1882 in the Church of the Holy Equal to the Apostles Myrrhbearer Mary Magdalene at the Teacher's Seminary of Prince Peter of Oldenburg. The baptismal recipients were LieutenantGeneral Isidor Frantsevich Stein and the daughter of the Chairman of the Poltava provincial Zemstvo Council Alexey Vladimirovich Zalensky, Olga Alekseyevna Zalenskaya ${ }^{56}$ (Sergey's cousin).

According to Sergey, he spent his childhood in Kharkov, in the house of his uncle, philologist, Professor A. A. Potebnya (1835-1891) ${ }^{57}$. It is documented that in 1891 Sergey entered the first class of the school named by K. May ${ }^{58}$ and graduated from the full course of the gymnasium with an average grade of 3.5 in 1900. In his autobiography, Sergey Stein writes that 'in the Gymnasium by K. May he studied under the guidance of Slavists, the students of the academician Lamasky, A. L. Lipovsky, V. A. Krakau, N. V. Yastrebov and V. N. Korablev' ${ }^{\prime 59}$.

Immediately after graduating from gymnasium, Sergey Stein entered the Imperial St. Petersburg University at the Faculty of Oriental Studies, but in November 1900 he applied for a transfer to the Faculty of Law, 'since languages do not correspond to either interests or abilities' ${ }^{60}$. In 1902, he applied to the St. Petersburg Archaeological Institute, where he graduated from the full course in 1904, and returned to the University for the first year of the Faculty of History and Philology, where he studied under Professor, historian of Russian literature, archeographer and palaeographer I. A. Shlyapkin (1858-1918). On the 21st of February 1906, the fourth-year student Sergey Stein applied for dismissal from the University and only in October 1909 returned to the seventh semester of the Faculty of Law, however, he did not finish the full course of the capital

56 TGASP, f. 7240 , inv. 2, ref. no. 4025 , sheet 4 .

57 Ibidem, sheet 8 .

58 Н.В. Благово, op. cit., part 1, p. 531 - the patronymic 'Vadimovich' is indicated incorrectly.

59 ‘в Гимназии К.Мая учился под руководством славистов, учеников академика Ламанского А.А. Яиповского, В.А. Кракау, Н.В. Ястребова и В.Н. Кораблева'. TGASP, f. 7240 , inv. 2, ref. no. 4025 , sheets $8-11$.

60 'так как языки не соответствуют ни интересам, ни способностям'. TGASP, f. 7240 , inv. 2, ref. no. 4025 , sheet 7 . 
University - he passed the state exams on the Faculty of Law in 1912 at the Imperial Kazan University ${ }^{61}$.

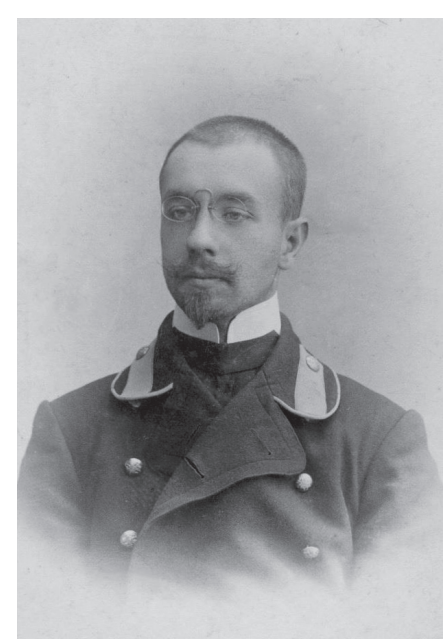

Photo 6. Sergey Vladimirovich Stein.

Published for the first time ${ }^{62}$.

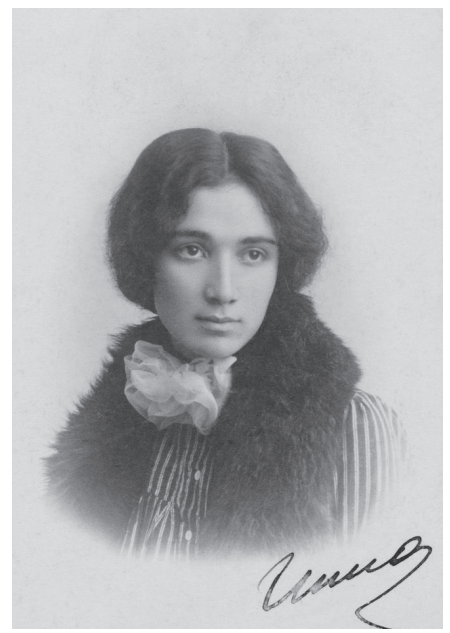

Photo 7. Inna Stein, nee Gorenko

(24.10.1904). Published for the first time ${ }^{63}$.

Since school years, Sergey was closely associated with the gymnasium students of Tsarskoye Selo, who were interested in poetry and literature ${ }^{64}$. In 1904, S. V.Stein married Anna Akhmatova's older sister, Inna Andreyevna Gorenko. Inna studied in the same class of the Women's Gymnasium and was a good friend of Sergey's sister, Natalia Vladimirovna Stein.

Later, Natalia Stein in her first marriage was married to a friend of Sergey Stein, the poet of the 'Silver Age', the literary critic Valentin Innokentyevich Annensky (1880-1936, pseudonym - Krivich), the son of the famous poet Innokenty Fedorovich Annensky.

S. V. Stein described his impressions of meetings with the classic in the following way ${ }^{65}$ :

${ }^{61}$ Ibidem, sheets 7, 28, 47, 61, 66; Sankt Peterburgskiy filial Arkhiva Rossiyskoy Akademii Nauk, f. 150, inv. 1, ref. no. 3.

62 Photo from the archive of A.G. Lazareva-Irvin.

63 Photo from the archive of A.G. Lazareva-Irvin.

$64 \mathrm{http} / /$ tsarselo.ru/yenciklopedija-carskogo-sela/istorija-carskogo-sela-v-licah/shteinsergei-vladimirovich-fon-1882-955.html\#.VlbR9NLhB2Q [accessed on: 29 II 2016].

65 А.В. Лавров, Р.Д. Тименчик, Иннокентий Анненский в неизданных воспоминаниях, 'Памятники культуры. Новые открытия' 1981, pp. 61-68. 


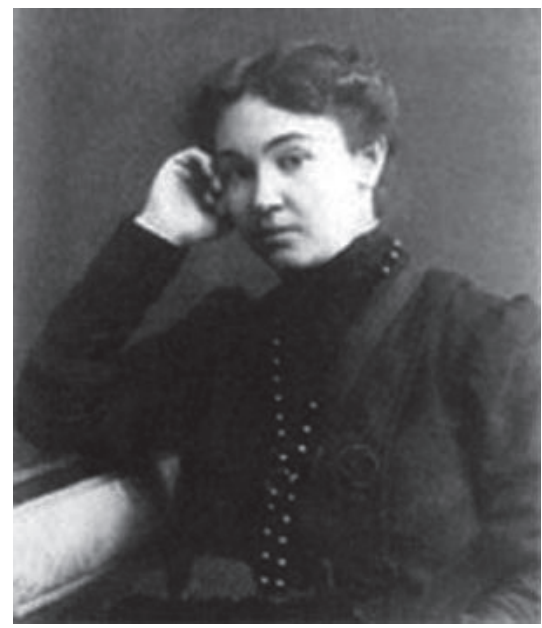

Photo 8. Natalia Vladimirovna Stein. Published for the first time ${ }^{66}$.

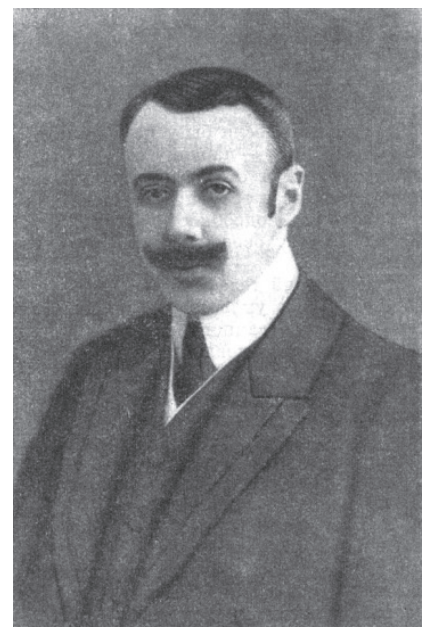

Photo 9. Valentin Innokentyevich Annensky.

'[...] It was a great happiness to know him as an intimate Innokenty Fedorovich, and not as a starched inspector of the St. Petersburg school district, or as a learned translator of Euripides, or as a 'Maitre' in the editorial office of the 'Apollon' magazine. He was a beautiful, versatile and all-responsive person - in the highest sense of the word. For the last seven years of his life I have enjoyed his close friendship, and one day I hope to tell you a great deal about him. To do what was planned thirteen years ago, when a collection of memoirs about Annensky was conceived - a man, a poet, a critic, a scholar of Hellenism. It did not take place, this collection, and meanwhile the circle of people close to Annensky has greatly thinned. And soon there will be no one to tell about him ${ }^{67}$. Unfortunately, Sergey Stein could not or did not have time to write full-fledged memoirs about I. F. Annensky.

Sergey Stein has developed confidential relationship with the young Anna Akhmatova. It was to him in a letter dated at February 2, 1907, that

66 Photo from the archive of A.G. Lazareva-Irvin.

67 ‘...] Это было большое счастье знать его именно интимным Иннокентием Федоровичем, а не накрахмаленным инспектором петербургского учебного округа, не ученым переводчиком Еврипида, не 'maitre'oм' в редакции журнала 'Аполлон'. Он был прекрасный, такой многогранный и всеотзывчивый человек в высоком значении этого слова. Семь последних лет его жизни я пользовался его дружественной близостью и когда-нибудь надеюсь рассказать о нем многое. Сделать то, что проектировалось еще тринадцать лет тому назад, когда был задуман сборник воспоминаний об Анненском - человеке, поэте, критике, ученом элдинисте. Он не состоялся, этот сборник, а между тем круг близких к Анненскому лиц сильно поредел. И скоро уже некому будет порассказать о нем'. 
she informed of her decision to marry Nikolay Gumilyov. Naturally, Sergey Stein and Nikolay Gumilyov were connected not only by close family relations, but also by common literary interests - in 1906 Stein reviewed the first collection of poems by Nikolay Gumilyov ${ }^{68}$. In turn, N. Gumilyov wrote a positive review of translations of Slavic poets made by S. V. Stein.

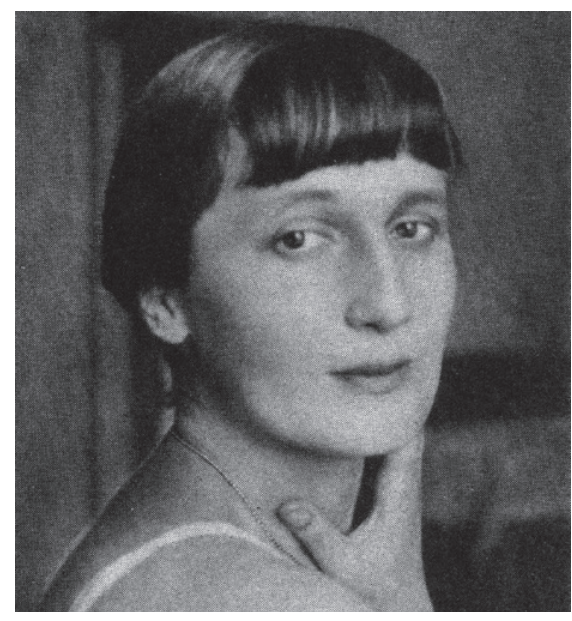

Photo 10. Anna Andreevna Akhmatova.

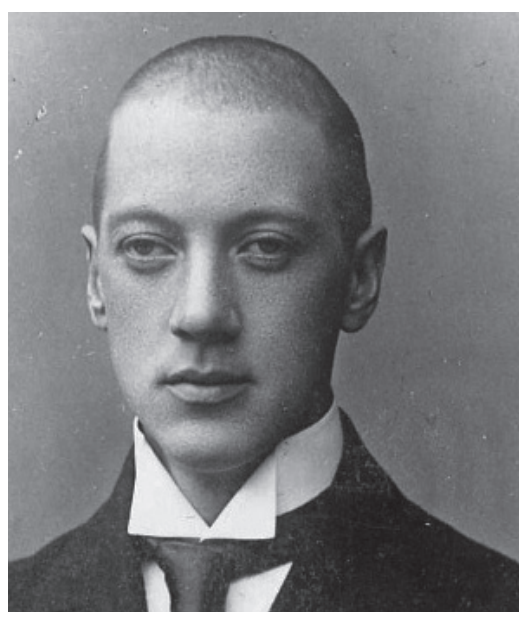

Photo 11. Nikolay Stepanovich Gumilyov.

On the 15th of July 1906, two years after the wedding, Inna Stein died at the age of 21. The next entry in the 'Petersburg Necropolis' refers specifically to Inna Andreyevna Stein: 'Stein-von, Nina (correctly 'Inna'. Auth.) Andreyevna, b. 5 December 1884, + 15 July 1906 (Kazan cemetery in Tsarskoye Selo' ${ }^{\prime 69}$. This can be confirmed by a report in the newspaper 'Novoe Vremya': 'Inna Andreyevna Gorenko died on July 15, 1906 in Lipitsy near Tsarskoye Selo' ${ }^{70}$.

By his second marriage, Sergey Stein was married to Ekaterina Vladimirovna Kolesova. In this marriage, a daughter, Lyudmila, was born, of whom we know nothing. The marriage was concluded in 1908 and ended no later than 1919, possibly due to Stein's emigration to Estonia. Later, Ekaterina Kolesova married a friend of Sergey Stein from Tsarskoye Selo, a writer, poet, and artist Erich Fedorovich Gollerbach (1895-1942).

68 С.В. Фон Штейн, Н. Гумилев: Путь конквистадоров, 'Слово' 1906, 360, p. 7.

69 'Штейн-фон, Нина (правильно 'Инна' - author's note) Андреевна, p. 5 декабря 1884, † 15 июля 1906 (Казанское кладбище в Царском селе)'. [В.И. Саитов] Великий князь Николай Михайлович, op. cit., p. 586.

70 ‘Инна Андреевна Горенко умерла 15 июля 1906 г. в Липицах близ Царского Села'. ‘Новое время' 1906, 10899. 
For all his passion for the shining world of the 'Silver Age'71, Sergey Stein had to take care of providing for his family, mother and younger sisters. In 1907-1914 Sergey Vladimirovich served as a secretary of the Direction of the Russian-Danube Shipping Company ${ }^{72}$, from 1914 a clerk of the legal office of the Department of State Savings Banks, from 1916 - a secretary of the editorial office of periodicals of the Department of State Savings Banks and by 1918 held the position of senior accountant of the chancellery of the Department of State Savings Banks $^{73}$.

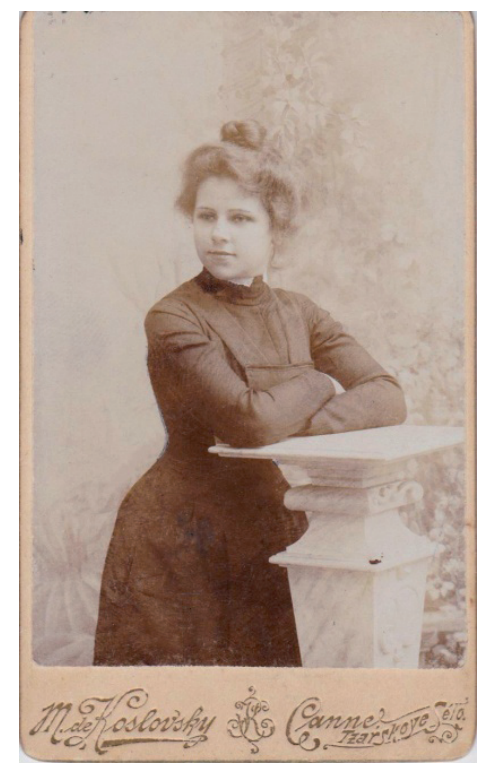

Photo 12. Ekaterina Vladimirovna Stein, nee Kolesova. Published for the first time ${ }^{74}$.

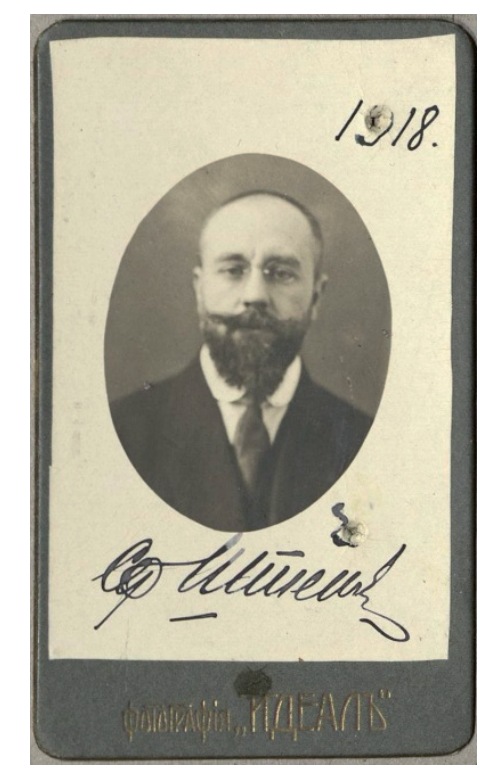

Photo 13. Sergey Vladimirovich Stein. Petrograd, $1918^{75}$.

Of course, Sergey Stein considered literature, history, and art to be the main meaning of his life. While studying at the University, he read a number of reports in the Circle for the study of the Encyclopedia of Law and in practical classes on the history of Russian law. He specialized in the study of Police law and worked on the essay 'Russian legislation on the press'. Later he was a scientific secretary of the Serbian branch of the

\footnotetext{
${ }_{71}$ Г.М. Пономарева, ор. cit., pp. 83-92.

72 Весь Петербург: Адресная и справочная книга на 1907 год, Санкт Петербург 1907, р. 806.

73 TGIASP, f. 740, inv. 1, ref. no. 57, sheet 2; TGASP, f. 7240, inv. 2, ref. no. 4025, sheets 3, 6.

74 Photo from the archive of A.G. Lazareva-Irvin.

75 TGASP, f. 7240 , inv. 2, ref. no. 4025 , sheet 1 b.
} 
Society of Oriental Studies, a member of the Petrograd Archaeological Institute, the Russian Bibliological and Bibliophile Societies, and the Professional Association of Literary Writers ${ }^{76}$.

Sergey Vladimirovich started his literary activity as a student-since 1900, he has been published in periodicals, he published articles on the history of literature in the magazinesand newspapers: 'Новоевремя',' Аитературный вестник', 'Славянские известия', 'Слово', 'Исторический Вестник', 'Живописное обозрение', 'Русский библиофил', 'Аукоморье' and others.

In 1907, Sergey Stein took a long trip to the Balkan Peninsula (Bulgaria and Serbia), collecting material for his book on the history of Slavic literature, which was published in $1908^{77}$.

In 1912, S. V. Stein began to collaborate with the Pushkin House at the Russian Academy of Sciences (now - IRLI), engaged in the acquisition and replenishment of assets. For this purpose, he made trips to Pskov (1914) - to collect materials concerning Alexander Pushkin in the villages of Mikhailovskoye, Petrovskoye, Trigorskoye; to Moscow (1916, 1917, 1919 ) - to search for the manuscripts of the first Russian translator of 'Faust' Huber (1814-1847), to analyse the library and archive of the art critic Prince A. I. Urusov (1843-1900), to search for the manuscripts of the bibliographer M. N. Longinov (1823-1875) and the correspondence of the poet F. I. Tyutchev; to Orel province (1918) - to get acquainted with the condition of the library of I. S. Turgenev.

In July 1919, Stein was accepted to the Pushkin House as a part-time volunteer for the position of acting custodian of the Museum.

In 1918, Stein for the first time experienced himself as a teacher - he taught a course in political economy at the Tsarskoye Selo Commercial School and a course in general aesthetics at the Tsarskoye Selo National Conservatory. In 1919, he lectured on the Tsarskoye Selo literary antiquity at the courses of the Commission for the Protection of Ancient Monuments and $\mathrm{Art}^{78}$.

However, Sergey Stein laurels of a writer, historian and teacher were not enough, and in August 1917, he was elected the member of the Pavlovsk City Duma and later became its Chairman ${ }^{79}$. In October 1919, 'by the will of the population, during the occupation of Pavlovsk by the troops

76 Ibidem.

77 С. Штейн, Славянские поэты: Николай I Черногорский, Иован Иованович Змай, Иован Илич, Воислав Илич, Иован Аучич, Антон Ащкери, Отон Зупанчич, Казимир Тетмиаиер, Карл Гавличек Боровский: Переводы и характеристики, Санкт Петербург 1908.

78 Rahvusarhiiv Tartus [hereinafter: EAA], f. 2100, inv. 2, ref. no. 1137, sheet 9.

79 TGIASP, f. 740 , inv. 1 , ref. no. 57. 
of General Yudenich, he again took over the administration of city affairs, and when the North-Western army retreated, he was forced to emigrate to Estonia'$^{80}$. Thus, at the end of 1919, Stein found himself in Estonia, where he obtained citizenship and a teaching position at the University of Tartu.

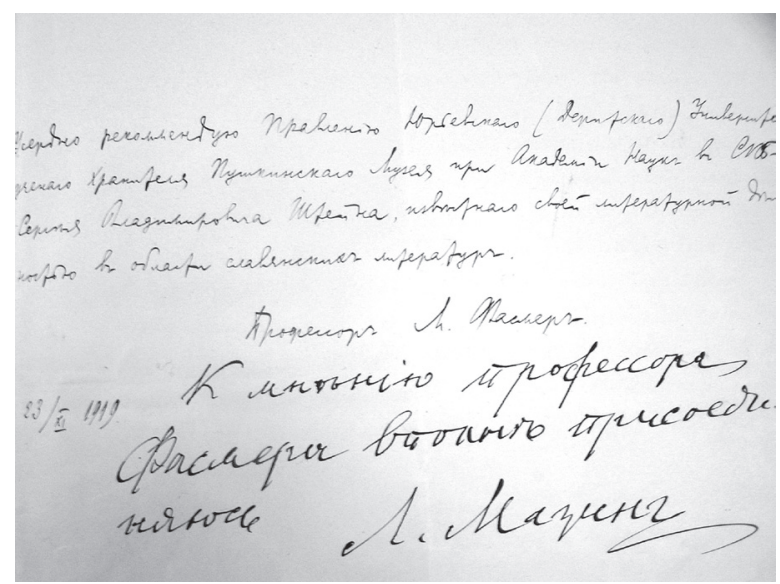

Photo 14. Recommendation to S.V. Stein, written by Max Fasmer and Leonard Mazing. Tartu, $1919^{81}$.

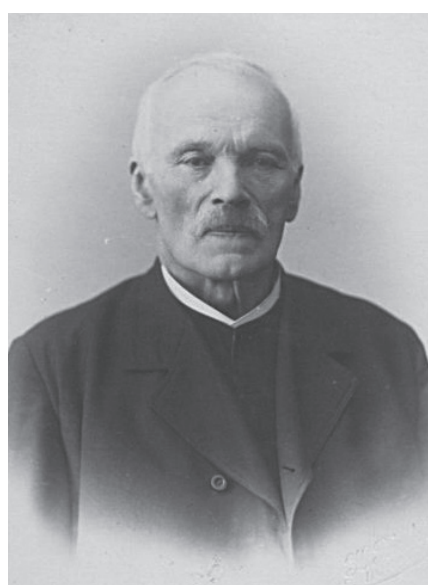

Photo 15. Leonard Karlovich Mazing (1845-1936) $)^{82}$.

The Estonian period of Stein's life is well described in the publications of our Estonian colleagues ${ }^{83}$, but the work with the original archival documents ${ }^{84}$ allows us to add several details to the biography. In December 1919 Stein was elected Privatdozent of the University of Tartu in the Department of Slavic Literature. It is important to note that Stein's recommendation to the Board of the University was given by another graduate of the Gymnasium named by K. May Professor Max Fasmer ${ }^{85}$,

80 ‘по воле населения, при занятии г. Павдовска войсками ген. Юденича вновь принял на себя управление городскими делами, и при отступлении Северо-Западной армии вынужден был эмигрировать в Эстонию'. ЕАА, f. 2100, inv. 2, ref. no. 1137, sheet 10.

81 Ibidem, sheet 4 .

82 University of Tartu Library, Section 6 Photos, Main photo collection, Fo Alb.2:108, http://dspace.ut.ee/handle/10062/44899 [accessed on: 29 II 2016].

83 Г. Пономарева, Т. Шор, ор. cit., pp. 163-173.

84 EAA, f. 2100, inv. 2, ref. no. 1137, ref. no. 1139.

85 Max-Julius-Friedrich Richard Vasmer (15 (28).02.1886 - 30.11.1962) - a famous researcher-etymologist, foreign member of the USSR Academy of Sciences, full member of the Saxon Academy of Sciences and Royal Prussian Academy of Sciences, member of the Academy of Sciences of Stockholm and Copenhagen, studied at the school named after K. May in 1896-1903 at the same time as S. Stein, he worked in the Tartu University in the early 1920s. М.Т. Валиев, Макс и Рихард Фасмеры - время и судьбы, in: Немиь в СанктПетербурге. Биографический аспект, nо. 7, Санкт Петербург 2013, pp. 291-303. 
describing him as a specialist 'known for his literary work in the field of Slavic literatures' ${ }^{86}$. From 1920 to 1928 Stein gave, with some intervals, lectures on the history of Slavic, Serbo-Croatian, Czech and Slovak, Bulgarian and, of course, Russian literature at the University of Tartu.

In parallel, Sergey Stein returned to journalism and political activity, taking an active part in the public life of the Russian Diaspora in Estonia. When the Russian Academic Group in Estonia was formed in Tallinn, he first joined the Group's Provisional Committee, and in April 1921 was elected to the Group's Board ${ }^{87}$ by the general meeting. He published articles on literary topics in the Newspapers 'Свободная Россия', the weekly 'Облака'. In the newspaper 'Последние известия' he published an obituary essay about Gumilyov ${ }^{88}$ and memories about Alexander Alexandrovich Blok ${ }^{89}$, a total of more than 240 articles. However, after taking over the newspaper 'Последние известия' in 1926, S. Stein could not cope with financial difficulties, and in 1927 the newspaper was closed, unable to compete with the Riga edition of 'Сегодня'.

Unfortunately, carelessness in calculations and inability to distribute energy led Stein to a number of events that damaged his reputation and caused his departure from Estonia. Such negative events include the loss of the election to fill the vacancy of Professor of Slavic Philology at the University of Tartu; the scandalous failure of Stein's doctoral dissertation; and the financial collapse of the newspaper.

S. Stein's position at the University was shaken by the retirement of its head, Professor L. Mazing ${ }^{90}$. As a result of the election of candidates for the vacancy, the Council voted by 14 votes in favour of Dr Adolf StenderPetersen, a lecturer at the University of Gothenburg, with one abstention ${ }^{91}$. The situation with the defence of the doctoral dissertation is described in the article of the above-mentioned Estonian literary critics:

'The defence of <dissertation> took place on the 21st of May 1928. The official opponents were professors V. Anderson and A. StenderPetersen. The defence, which lasted more than 7 hours, was noted in the

86 EAA, f. 2100, inv. 2, ref. no. 1137, sheet 3.

87 Ibidem, sheet 11.

88 С.В. Штейн, Погиб поэт..., ‘Последние известия' 1921, 228.

89 С.В. Штейн, Воспоминания об Александре Александровиче Блоке, 'Последние известия' 1921, 203, 205.

90 Leonard Karlovich Masing (1845-1936) - Doctor of Philology, Professor-Slavist of the Dorpat/Yuryev/Tartu University.

91 EAA, f. 2100, inv. 2, ref. no. 1139, sheets 13-18. Adolf Stander-Petersen (1893-1963) - Danish Slavist. He was born and received education in St. Petersburg. From 1927 to 1931 he headed the Department of Slavistics at the Tartu University. One of the founders (1931) of the Department of Slavistics in the Aarhus University, Denmark. 
newspapers 'Postimees' and 'Uliopilasleht' as the longest in the history of the University. The most serious opponent was A. Stender-Petersen since he had already dealt with this problem before. [...] The Opponent severely criticized the work by S. Stein presented to the defence. The Author was blamed for the lack of knowledge of German literature, the absence of some references, and the use of faulty Russian translations of Hoffmann in the text at the end of the 19th century, rather than in the 1820s and 30s. $[\ldots]$ in some cases, there were no corresponding references to the works that were used in the text of the dissertation, which later gave rise to accusations of plagiarism by S. Stein ${ }^{\prime 22}$.

In June 1928, S. Stein left for Riga, leaving behind a lot of debts - the books that were not returned to the University library, a debt to the Russian Archive in Prague, incomplete payments with the bookstore 'Vozrozhdenie', a shortage of funds intended to help S. N. Molchanov. The faculty Council petitioned the University Board to remove Stein from the faculty with the wording 'for misconduct'. At the same time, he was removed from the Russian Teachers' Association and Russian Academic Group. In Estonia, Sergey Stein became a 'persona grata of pop'.

In Riga, Stein was unable to find place to apply for his talents and applied for the vacant position of Russian language teacher at the Libava Russian Gymnasium. However, even here he showed a quarrelsome character, and came into conflict with the Director of the Gymnasium, D. A. Tikhonravov. 'On the 1st of March, [1929 - author's note] at a closed meeting of the Pedagogical Council, the relations between Stein and Tikhonravov escalated so much that it was only thanks to the presence of the other members of the Council that a collision was avoided. The unfortunate incident caused great excitement in the Libava teaching circles, as well as among parents. It was decided to send a telegram to the Minister of Education and the Russian Department, in which parents, teachers and

92 ‘Защита <диссертации> проходила 21 мая 1928 г. Официальными оппонентами выступали профессора В. Андерсон и А. Стендер-Петерсен. Защита, продолжавшаяся более 7 часов, была отмечена в газетах 'Postimees' и 'Uliopilasleht' как самая длительная в истории университета. Наиболее серьезным оппонентом оказался А. СтендерПетерсен, поскольку он уже раньше занимался этой проблемой. [...]. Оппонент подверг представленную к защите работу С. Штейна суровой критике. Автору ставилось в вину недостаточное знание немецкой дитературы, отсутствие некоторых ссылок, использование в тексте неисправных русских переводов Гофмана конца XIX в., а не 1820-30-х гг. [...] в ряде случаев отсутствовали соответствующие ссылки на работы, которые использовались в тексте диссертации, что в дальнейшем дало повод к обвинениям С. Штейна в плагиате'. Г. Пономарева, Т. Шор, Сергей Штейн: миф и реальность, іп: Труды по русской и славянской филологии. Аитературоведение, по. 3, Tartu 1999, pp. 317-331. 
even students asked to take measures to eliminate S. V. Stein ${ }^{\prime 93}$.

In 1931, S. V. Stein moved to Belgrade, gave a number of lectures at the Serbian Kolarac People's University, and published a number of articles on literary topics in the Yugoslav periodical press. This period is described in the article by the historian of Russian emigration A. B. Arsenyev ${ }^{94}$, who kindly provided his materials for this publication.

The following paragraph is based on the information provided by A. B. Arsenyev.

In 1933, Stein moved to Dalmatia. In his autobiography ${ }^{95}$, he writes that in 1930-1936, he 'studied the Serbo-Croat language'. He spent autumn studying Russian manuscripts in the Montenegrin State Archives in Cetinje, where he went from Dubrovnik, where his family lived. On the 12th of March 1934 Sergey Vladimirovich returned to the Roman Catholic faith of his ancestors ${ }^{96}$. Since 1935 he held the post of Professor in the Higher Philosophical and Theological School of the Dominican order in Dubrovnik, where he taught the history of Russian religious philosophy and Russian language. In Dubrovnik, he was treated with great respect, especially among the Roman Catholic clergy. The anniversaries of Professor Stein - 35 years (1935) and 40 years (1940) of his literary and scientific activity - were marked in Dubrovnik by the publication of a brochure about him $^{97}$ and articles in several Yugoslav magazines. The library of the Franciscan monastery in Dubrovnik still holds almost all of his works published in Yugoslavia. As early as 1935 Sergey Vladimirovich had major works prepared for publication, which apparently were not published: 'Черногорский владыка Петр І в 1806 г.: Заметки о прошлом югославско-российских связей, по материалам Государственного архива в Цетинье'; ‘Дубровник и Россия'; ‘Среди русских - друзей южных славян: Книга воспоминаний'; 'Из истории мистики эпохи романтизма и Пушкин и его эпоха'.

93 '1 марта [1929 г. - author’s note] на закрытом заседании Педагогического совета отношения между Штейном и Тихонравовым обостридись настолько, что только благодаря присутствию остальных членов совета удалось избежать столкновения. Прискорбное происшествие вызвало большое возбуждение в Аибавских учительских кругах, а также среди родителей. Было решено отправить телеграмму Министру образования и Русскому отделу, в которой родители, учителя и даже учащиеся просят принять меры для устранения С.В. Штейна'. ЕAA, f. 2100, inv. 2, ref. no. 1137, sheet 65.

94 А.Б. Арсеньев, op. cit., pp. 281-322.

95 Abkürzung für Universitätsarchiv München [hereinafter: UAM], ref. no. E-II-3238.

96 S. Stejn, Povest moga obracanja sa pravoslavlja na katolicizam, Zagreb 1940.

97 Idem, Njegov rad u korist jugoslavensko-ruskog zbliћavanja o 35-godi snjici njegove naucno-knjizevne djelatnosti (1900-1935), Dubrovnik 1935, p. 21. 
In the autobiographical book Moj put $k B o g u^{98}$ we first find mention of the name and photo of Sergey Stein's third wife, Margarita R. von Stein ${ }^{99}$.

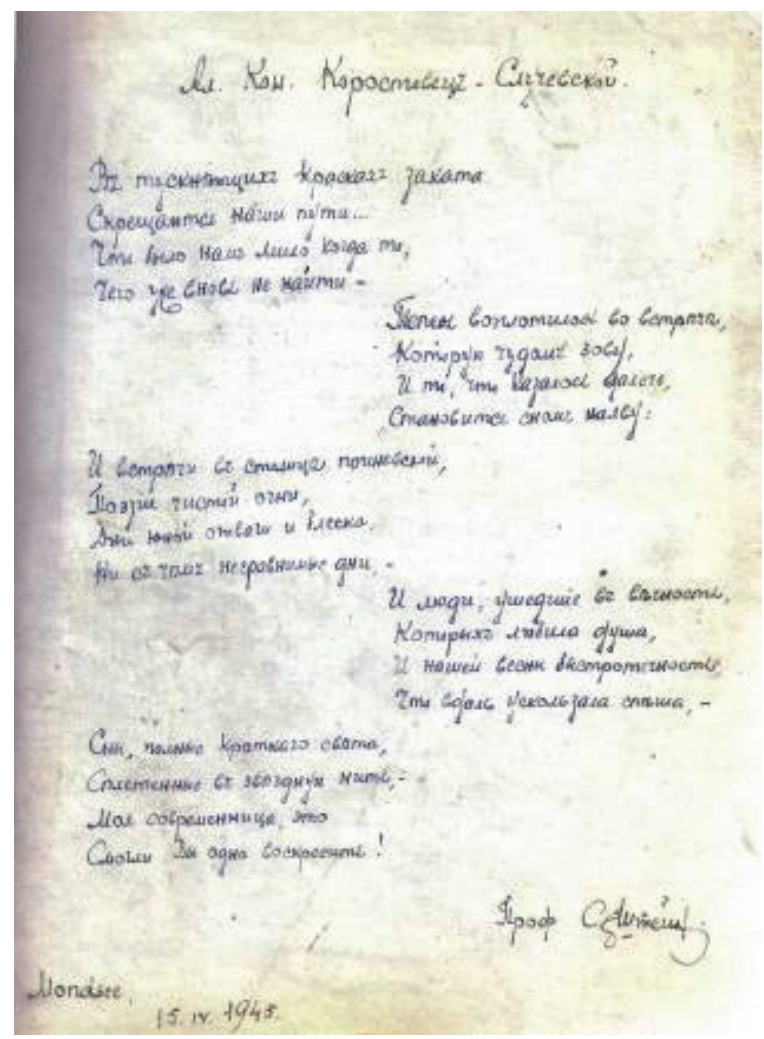

Photo 16. The note by S. Stein into the album of A.K. Korostovets-Sluchevskaya. Mondsee, Austria, 15.04.1945.

For a long time we could not find information about the fate of Sergey Stein after 1940. The only thing that could be said for certain was that in April 1945, Sergey Stein spent some time in the town of Mondsee (Austria) $)^{100}$, as evidenced by the note ${ }^{101}$, he left in the album of his good

98 S.V. Štejn, Moj put k Bogu, pp. 100-101.

99 Margaret R. von Stein (nee Frentz, 2.3.1889-?) - the daughter of the Russian Court artist of German origin Rudolf Ferdinandovich (Fedorovich) Frentz (1831 - 24.12.1918). Marriage with S. Stein concluded on 1.12.1919. UAM, ref. no. E-II-3238.

${ }^{100}$ Mondsee is a small town located at the northern end of the lake of the same name, in the Federal state of Upper Austria near Salzburg.

101 Родные отражения. По страницам альбомов семьи Случевских в годы эмиграции, ед. by И.Е. Иванченко, Москва 2014, Annex, p. 2. 
friend Alexandra Konstantinovna Sluchevskaya-Korostovets ${ }^{102}$. After a long search, we managed to find Stein's personal file at the University of Munich $^{103}$, and thanks to the support of Natalia Vladimirovna Stein's greatgranddaughter, Anna Lazareva-Irvin, we recently received a complete photocopy of the documents. Now we can confidently reconstruct the events of the last seventeen years of the scientist's life. In 1942, Stein left Yugoslavia and until 1945 worked as a research librarian at the city library of Bromberg in West Prussia. From 1945 until autumn of 1948, he served as a research librarian and Docent at the 'Berchmanskolleg', the Higher School of Philosophy and Theology in Pullach, near Munich. On the 29th of July 1949, Stein was confirmed as Privatdozent (Umhabilitierung) of the Faculty of Philosophy at the University of Munich. It is interesting to note that in documents of this time he was named as Sergius Dominicus von Stein ${ }^{104}$. On the 24th of September 1953 Stein was elected a visiting Professor of Russian literature ${ }^{105}$. Unfortunately, the scientist's career was interrupted by his sudden death on the 8th of September 1955, as it was reported in the annual report of the University of Munich for 1954-1955 ${ }^{106}$.

From the other branches of the Stein family, the line of Sergey's sister, Natalia Vladimirovna Stein, is quite well traced. Natalia Vladimirovna was born in Saint Petersburg on the 23rd of October 1885. In 1902, she graduated from the Tsarskoye Selo Women's Gymnasium, receiving the Certificate for the title of home teacher. While studying at the gymnasium, Natalia was friendly with Inna Andreyevna Gorenko, who later became the wife of Sergey Stein. As previously mentioned, in her first marriage, Natalia Vladimirovna was married to the Russian poet, philologist and memoirist Valentin Innokentyevich Annensky, who was connected by friendly ties with Sergey Stein. The marriage of Natalia Vladimirovna and V. I. Annensky lasted almost a decade and broke up in 1915, there were no children in this marriage. Natalia married for the second time in 1916 to Valentin Platonovich Hmara-Borshchevsky, the 'favourite grandson' of I. F. Annensky (from the stepson of Platon Petrovich Hmara-Borshchevsky (1.11.1863, Slivitskoe village, Belsky uyezd, Smolensk province-1924,

${ }^{102}$ Alexandra Konstantinovna Sluchevskaya-Korostovets (1890-1977) - the youngest daughter of the poet K. K. Sluchevsky (1837-1904), whose famous 'Fridays' were certainly visited by Sergey Stein.

${ }^{103}$ UAM, ref. no. E-II-3238.

${ }^{104}$ S. Stein Sergius v. Dozent Adelheidstr. 10 App. 4. Münchner Stadtadressbuch, München 1953, p. 873.

105 ‘Jahrbücher für Geschichte Osteuropas' 1953, 1, 4, pp. 456-458.

${ }^{106}$ Ludwig-Maximilians-Universität-München. Jahresbericht des Rektors Prof. Dr. Alfred Marchionini über das Akademische Amtsjahr 1954/55, München 1955, p. 10 
Orenburg)). As you know, the wife of I. F. Annensky, Nadezhda (Dina) Valentinovna Hmara-Barshchevskaya (1841, Slivitskoe village, Belsky uyezd, Smolensk province - 9.04.1917, Petrograd, buried at the Kazan cemetery in Tsarskoye Selo), had two sons from her first marriage - Platon Petrovich and Emmanuel Petrovich. The daughter Natalia and the son Innokenty, named after his grandfather, were born in the marriage of Natalia Vladimirovna and Valentin Platonovich Hmara-Borshchevsky. In the service record of Valentin Platonovich Hmara-Borshchevsky, it is written that until 1913 he studied at the Levitskaya School in Tsarskoye Selo, in 1915 he graduated from the Oranienbaum Praporszczik School and had an additional officer's exam at the Page Corps in the same year. He served in the Life Guards of His Majesty's 1st Rifle Regiment, participated in the battles of the First World war, retired from the Regiment due to contusion in August 1917. In Soviet times, he worked as a military specialist at the Belsk UVK (Smolensk region), then as a senior pyrotechnic engineer at the scientific and test engineering range and the Military Engineering Department of the Red Army. In the 1930s, he was commissioned for health reasons, died in 1944 in the evacuation from exhaustion and stomach ulcers, and was buried in the village of Naberezhnye Morkvashi (Tatarstan). Natalia Vladimirovna graduated from accounting courses and worked at an aviation plant in Moscow. At the end of 1941, Natalia Vladimirovna and her husband evacuated to Tatarstan. Their daughter Natalia and her child joined their parents in 1943. Natalia Valentinovna, graduated from the Moscow Pharmaceutical Institute, worked first as a nurse, and then as the head of the pharmacy of the evacuation hospital in Pustye Morkvashy (Tatarstan) ${ }^{107}$.

Natalia Vladimirovna's son, Innokenty Valentinovich HmaraBorshchevsky, spent four years on the fronts of the Great Patriotic war and tragically died on the eve of victory, on the 8th of May 1945, in the battles for the liberation of Lodz in Poland.

In 1945, Natalia Vladimirovna returned to Moscow with her daughter Natalia and granddaughter Valentina, where she lived until the end of her life. Despite constant travel, military hardships and evacuation, Natalia Vladimirovna kept the family archive with photos and documents. Thanks to this extraordinary loyalty to family memory, we can now see a number of photos, many of which are published for the first time in this article.

Unfortunately, very little is known about the fate of the twin sisters Sofia and Elena, only one photo of them in their infancy has been preserved. Sofia Vladimirovna graduated from the Higher Women's courses in

${ }^{107}$ The following is based on the information provided by Anna Lazareva-Irvin. 


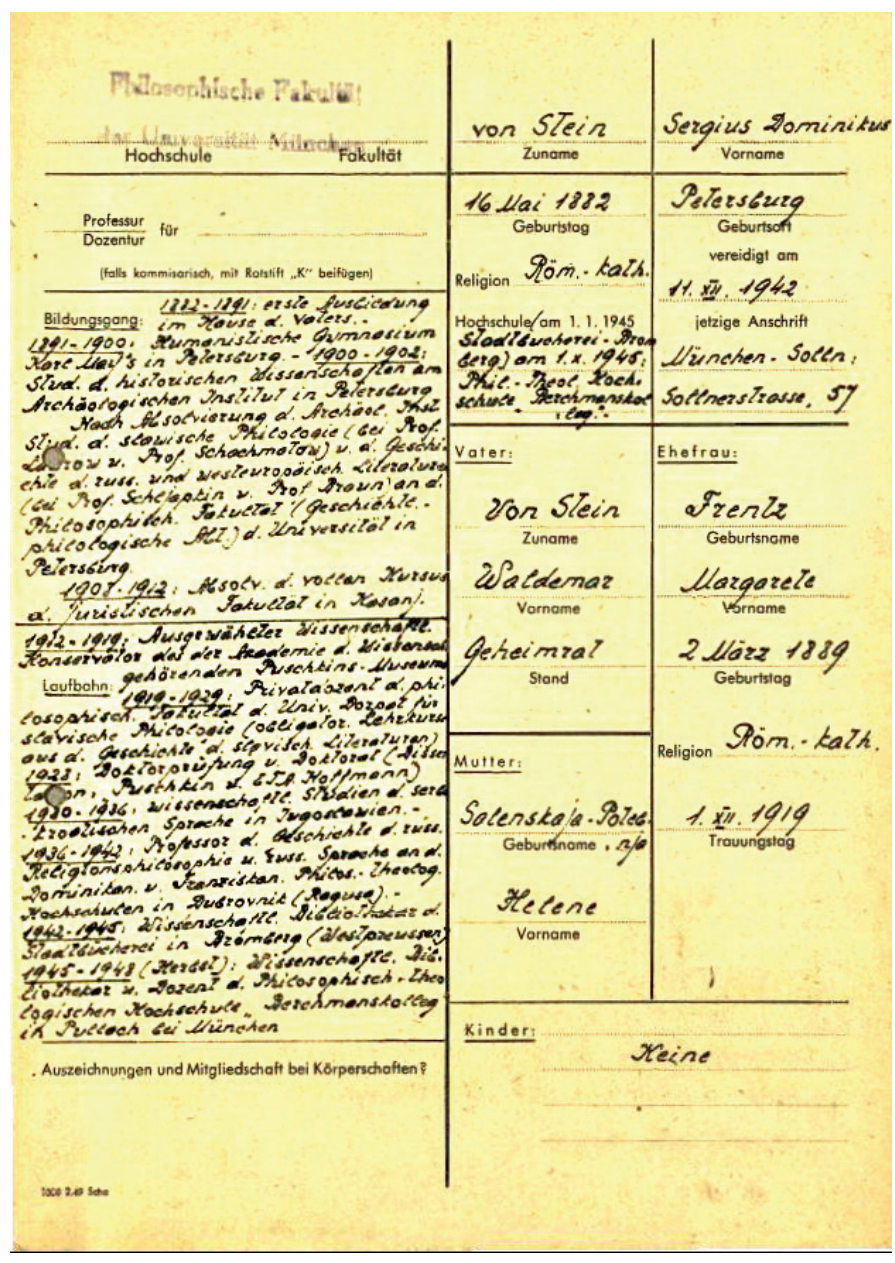

Photo 17. Personal File of S. Stein. Archives of the University of Munich UAM E-II-3238.

Saint Petersburg. Elena Vladimirovna received medical education and participated in scientific expeditions to Central Asia. Several watercolour drawings made by Elena Vladimirovna in Mongolia in 1914, where she worked together with Emmanuel Petrovich Hmara-Borshchevsky ${ }^{108}$, have been preserved in the family archive.

${ }^{108}$ E.P. Hmara-Borshchevsky (1865, Slivitskoe village, Smolensk province - 15.06.1921, Mianduh station, China, buried in Harbin in the old cemetery) - an uncle of Valentin Platonovich Hmara-Borshchevsky, a graduate of the Military Medical Academy in St. Petersburg, served as an assistant to the chief doctor of the Chinese Far East Railway, led anti-plague activities in Manchuria. 
In the marriage of Anna Isidorovna Stein with Professor V. V. Zalensky, an only daughter, Alexandra, was born. The Professor's life ends tragically in 1918, and nothing is known about the fate of his wife and daughter.

Here we stop our story about the family history of the Stein family. We have not been able to find descendants of the family within our homeland. However, we were able to establish a connection with the descendants of Natalia Vladimirovna Stein in the United States, who gave us several unique photos, some of which are used in this publication. It is hoped that some of the descendants of this family survived in Germany or Poland, but this is the task of the next study ${ }^{109}$.

(translated by Margarita Sviridova)

\section{REFERENCES}

\section{Archival sources}

Abkürzung für Universitätsarchiv München:

ref. no. E-II-3238.

Otdel Rukopisey Instituta Russkoy Literatury:

f. 541, ref. no. 1.

Rahvusarhiiv Tartus:

f. 2100, inv. 2, ref. no. 1137.

Rossiyskiy Gosudarstvennyy Istoricheskiy Arkhiv:

f. 613, inv. 1, ref. no. 104; f. 733, inv. 150, ref. no. 1151; inv. 147, ref. no. 98; f. 776, inv. 21, part

1, ref. no. 53; f. 779, inv. 2, ref. no. 431; f. 1343 , inv. 22 , ref. no. 721 ; inv. 24 , ref. no. 2637;

inv. 33, ref. no. 2704; f. 1349, inv. 3, ref. no. 2537.

Rossiyskiy Gosudarstvennyy Voyenno-Istoricheskiy Arkhiv:

f. 400, inv. 12, ref. no. 2121; f. 409, inv. 2, ref. no. 40449.

Sankt Peterburgskiy filial Arkhiva Rossiyskoy Akademii Nauk:

f. 150, inv. 1, ref. no. 3 .

Tsentral'nyy Gosudarstvennyy Arkhiv Sankt Peterburga:

f. 7240 , inv. 2, ref. no. 4025 .

${ }^{109}$ I would like to thank all our friendly colleagues for their support and assistance. First of all, I would like to thank our friend and colleague Tatyana Lvovna Modzalevskaya (St. Petersburg), the researcher of the history of Russian emigration in Yugoslavia Alexey Borisovich Arsenyev (Novi Sad, Serbia), local historian Vyacheslav Dmitrievich Kirievsky (Shostka, Sumy region, Ukraine), colleague and invaluable assistant Irina Leinonen (Lausha, Thuringia, Germany), permanent and active associate Natalia Lachinova (Tallinn, Estonia), a young friend, Candidate of Philological Sciences Polina Korolkova (Moscow-Zagreb), a tireless collector of tribal stories of our compatriots Irina Evgeniyevna Ivanchenko (Narva, Estonia), the great-granddaughter Natalia Vladimirovna Stein, Anna Lazareva-Irvin (USA) and, of course, the main, long-term and invaluable assistant, critic, editor and secretary in one person - my wife Natalia Valieva (St. Petersburg). 
Tsentral'nyy Gosudarstvennyy Istoricheskiy Arkhiv Sankt Peterburga:

f. 19, inv. 101, ref. no. 63; f. 530, inv. 1, ref. no. 112.

University of Tartu Library:

Section 6 Photos, Main photo collection, Fo Alb.2:108.

\section{Printed sources}

'Jahrbücher für Geschichte Osteuropas' 1953, 1, 4.

'Novoye vremya' 1906, 10899.

\section{Studies}

Arsen'yev A.B., Russkaya emigratsiya v Dubrovnike. 1918-1921 gg., 'Novyy zhurnal' 2010, 260.

Blagovo N.V., Shkola Navasil'yevskom ostrove, part 1, Sankt Peterburg 2005.

Vagnery-otaptechnoystoykidogeneralaflota, in:Nemtsyv Sankt-Peterburge. Biograficheskiy.aspekt, no. 9, Sankt Peterburg 2015.

Valiyev M.T., Maks i Rikhard Fasmery - vremya i sud'by, in: Nemtsy v Sankt-Peterburge. Biograficheskiy aspekt, no. 7, Sankt Peterburg 2013.

Valiyev M.T., Klebanov A.F., Prusskiye-russkiye Tseydlery, 'Istoriya Peterburga' 2011, 3, 4.

Valiyev M.T., Leynonen I., Uchitel' nemetskogo, 'Rybinkaya sreda' 2014, 5.

Ves' Peterburg: Adresnaya ispravochnaya kniga na 1907 god, Sankt Peterburg 1907.

Lavrov A.V., Timenchik R.D., Innokentiy Annenskiy $v$ neizdannykh vospominaniyakh, 'Pamyatniki kul'tury. Novyye otkrytiya' 1981.

Ludwig-Maximilians-Universität-München. Jahresbericht des Rektors Prof. Dr. Alfred Marchionini über das Akademische Amtsjahr 1954/55, München 1955.

Münchner Stadtadressbuch, München 1953.

Ponomareva G.M., Vospominaniya S. Shteyna o poetakh-tsarskoselakh (I. Annenskiy, N.S. Gumilev, A.A. Akhmatova), in: Slavica Helsingiensia, vol. 11, Studia Russica Helsingiensia et Tartuensia III: Problemy russkoy literatury i kul'tury, eds. L. Byckling, P. Pesonen, Helsinki 1992.

Ponomareva G., Shor T., Sergey Shteyn: mif $i$ real'nost', in: Trudy po russkoy $i$ slavyanskoy filologii. Literaturovedeniye, no. 3, Tartu 1999.

Ponomareva G., Shor T., Slavist Sergey Shteyn i Tartuskiy universitet (1919-1928), in: Russkiye vne Rossii: Istoriya puti, Tallin 2008.

Ravdin B.V., Russkaya filologiya $v$ Tartuskom universitete, ‘Uchenyye zapiski Tartuskogo universiteta. Trudy istoriko-filologicheskogo fakul'teta' 1954.

Rodnyye otrazheniya. Postranitsam al'bomov sem'i Sluchevskikh v gody emigratsii, ed. I. Ye. Ivanchenko, Moskva 2014.

[Saitov V.I.] Velikiy knyaz' Nikolay Mikhaylovich, Peterburgskiy nekropol', vol. 2, Sankt Peterburg 1912.

Shteyn S., Slavyanskiye poety: Nikolay I Chernogorskiy, Iovan Iovanovich Zmay, Iovan Ilich, Voislav Ilich, Iovan Duchich, Anton Ashkerts, Oton Zupanchich, Kazimir Tetmayyer, Karl Gavlichek Borovskiy: Perevody i kharakteristiki, Sankt Peterburg 1908.

Shteyn S.V., N. Gumilev: Put' konkvistadorov, 'Slovo' 1906, 360.

Shteyn S.V., Pogib poet...,'Posledniye izvestiya' 1921, 228.

Shteyn S.V., Vospominaniya ob Aleksandre Aleksandroviche Bloke, 'Posledniye izvestiya' 1921, 203, 205.

Shteyn V.I., Artur Shopengauer kak chelovek i myslitel' (1788-1860): Opyt biografii, vol. 1, Sankt Peterburg 1887.

Shteyn V.I., Gr. Dzh. Leopardi (1798-1837) i yego pessimizm, Moskva 1891.

Shteyn V.I., Graf Dzhiakomo Leopardi (1798-1837) i yego teoriya infelicita, Sankt Peterburg 1891. 
Stejn S., Njegov rad u korist jugoslavensko-ruskog zblihavanja o 35-godi snjici njegove naucno-knjizevne djelatnosti (1900-1935), Dubrovnik 1935.

Stejn S., Povest moga obracanja sa pravoslavlja na katolicizam, Zagreb 1940.

Štejn S.V., Moj put k Bogu: Vjerske uspomene, Zagreb 1940.

Zalenskiy V.V., [Avtobiografiya], in: Materialy dlya biograficheskogo slovarya deystvitel'nykh chlenov imp. Akademii nauk, vol. 3, part 1, Petrograd 1915.

\section{Web sources}

http://dokumente.ios-regensburg.de/amburger/index.php?id=45691\& mode=1 [accessed on: 2 VIII 2016].

http://dspace.ut.ee/handle/10062/44899 [accessed on: 29 II 2016].

http://tsarselo.ru/yenciklopedija-carskogo-sela/istorija-carskogo-sela-v-licah/Stein-sergeivladimirovich-fon-1882-955.html\#.VlbR9NLhB2Q [accessed on: 29 II 2016].

\section{STRESZCZENIE}

Przedmiotem zainteresowania $\mathrm{w}$ niniejszym artykule jest historia rodziny Stein. W tekście przedstawione zostały unikalne dane genealogiczne o siedmiu pokoleniach rodu. Rodzina Stein, zgodnie z legenda, przeniosła się do katolickiej Polski w drugiej połowie XVI w. po zwycięstwie Reformacji w Niemczech. Przedstawiciele rodziny Stein służyli władcom Polski, Rosji i Austrii. W danym artykule uwaga zostaje skupiona na rosyjskiej gałęzi rodu, w której można odnaleźć m.in. oficerów, urzędników państwowych, literatów, czy też dziennikarzy. Jednym z głównych bohaterów publikacji jest słynny filolog i slawista Siergiej Władimirowicz Stein (1882-1955). Po raz pierwszy udało się dokładnie odtworzyć wydarzenia z ostatnich piętnastu lat życia S. W. Steina. W artykule znajduje się ponadto duża ilość ilustracji. Dla większości z nich jest to pierwsza publikacja.

Słowa kluczowe: genealogia, wywód genealogiczny, Stein, Rosja, Sankt Petersburg, Dorpat, Dubrownik, Monachium

\section{ABOUT THE AUTHOR}

Murat Valiyev - Project Head of 'Society of Karl May School Friends' (www.kmay.ru), independent researcher, genealogist. 